\title{
"REASON AND PASSION": THE CONSTITUTIONAL DIALETIC OF FREE SPEECH AND OBSCENITY
}

\author{
JoHN M. FINNIS $\dagger$
}

In recent obscenity cases, the Supreme Court has been attempting to define the constitutional meaning of "speech." 1 This is not as banal a statement as it may seem, for there are critics, both on and off the Court, who think that the Court's task is to define "freedom."

Some advocate boundless freedom in this area. For them, obscenity raises no special problems of definition, and is simply an exercise of speech or press presenting dangers which are remote and disputable, rather than clear and present. From this point of view, exemplified by Justices Black ${ }^{2}$ and Douglas, ${ }^{3}$ the only relevant distinction is that between "speech" and "conduct." Obscenity is selfevidently a matter of "expression of ideas" as opposed to "conduct," and so the only remaining question is rhetorical: Does the Constitution permit a line to be drawn between good ideas and bad?

Other critics, however, have refused to be bluffed by rhetorical questions. They would limit freedom of speech only to the extent required by a careful balancing with other values. This tradition, exemplified by Justices Frankfurter ${ }^{4}$ and Harlan, ${ }^{5}$ demands a strenuous examination of the concept of obscenity in order to reveal the vice it may connote and the values it may threaten. ${ }^{6}$ In each individual case, the courts must balance the requirements of free speech against the

†LL.B. 1961, Adelaide University, D.Phil. 1966, Oxford University. Fellow of University College, Oxford.

1 There is a distinction between "speech" and "press," but generally "expression" encompasses both. Cf. Lockhart \& McClure, Literature, the Law of Obscenity and the Constitution, 38 MrN. L. Rev. 295, 299 n.31 (1954).

2 See, e.g., Ginzburg v. United States, 383 U.S. 463, 476 (1966) (Black, J., dissenting); Mishkin v. New York, 383 U.S. 502, 517-18 (1966) (Black, J., dissenting).

3 See, e.g., Ginzburg v. United States, 383 U.S. 463, 491-92 (1966) (Douglas, J., dissenting); A Book Named "John Cleland's Memoirs of a Woman of Pleasure" v. Attorney General, 383 U.S. 413, 433 (1966) (Douglas, J., concurring) [hereinafter cited as Memoirs v. Massachusetts].

“See, e.g., Kingsley Int'l Pictures Corp. v. Regents of Univ. of N.Y., 360 U.S. 684, 691 (1959) (Frankfurter, J., concurring).

5 See, e.g., Memoirs v. Massachusetts, 383 U.S. 413, 455 (1966) (Harlan, J., dissenting) ; Roth v. United States, 354 U.S. 476, 496 (1957) (Harlan, J., concurring).

B Cf. P. Kauper, Crvm Liberties and the Constitution 58-60, 111-26 (1962); Lockhart \& McClure, Censorship of Obscenity: The Developing Constitutional Standards, 45 MINN. L. REv. 5 (1960); Lockhart \& McClure, supra note 1, at 373-87. 
evils which American society believes will flow from certain expressions of ideas. ${ }^{7}$

Both these schools have tended unreflectingly to tie the problem of obscenity to traditional doctrines developed in the more general context of free speech, for both fallaciously assume that obscenity involves the expression of ideas. Both schools thus fail to discern the core problem of defining "speech," or to appreciate the bedrock concept which underlies the prevailing attempts by the Court to solve this problem. ${ }^{8}$ This concept, which stands in sharp contrast to the two traditional perspectives just outlined, is that obscene utterances "are no essential part of any exposition of ideas." 9

The aim of this article is to sketch the intellectual basis of this newer perspective, to amplify its background, and to indicate the way in which it has shaped the substantive constitutional law on obscenity.

Obscenity involves the expression of "ideas," as that term is commonly used and understood. However, for Mr. Justice Brennan, there are some communications which have "saving intellectual content" 10 and others, including obscenity, which involve neither the exposition nor advocacy of ideas. ${ }^{11}$ Thus, he describes the reader of obscenity as looking "for titillation, not for saving intellectual content." 12 This contrast, much relied upon by Mr. Justice Brennan in the obscenity cases, corresponds to a distinction between two often competing aspects of the human mind: the intellect or reason and the emotions or passions. Since Mr. Justice Brennan would agree with a characterization of protected first amendment "speech" as "the communication of information or opinion," 13 "the exposition of ideas" 14

7 See, e.g., Kingsley Int'l Pictures Corp. v. Regents of Univ. of N.Y., 360 U.S. 684, 708 (1959) (Harlan, J., concurring); id. at 694-97 (Frankfurter, J., concurring).

8 The problem of defining "speech" to exclude obscenity is briefly noted in Cairns, Paul \& Wishner, Sex Censorship: The Assumptions of Anti-Obscenity Laws and the Empirical Evidence, 46 MnNN. I. Rev. 1009, 1012-13 (1962). Cf. T. MurPHy, CenSORSHIP: GOVERNMENT AND OBSCENITY 120-29 (1963). In both sources, however, the constitutional problem is muddled with the problem of why obscenity should or should not be proscribed. See also Slough \& McAnany, Obscenity and Constitutional Freedom, 8 ST. Lours U.L.J. 279, 347-48, 455-56, 476 (1964); Note, Obscenity Prosecation: Artistic Value and the Concept of Inmminity, 39 N.Y.U.L. REv. 1063, 1084-86 (1964).

${ }^{\circ}$ Chaplinsky v. New Hampshire, 315 U.S. 568,572 (1942), quoted with emphasis in Roth v. United States, 354 U.S. 476, 485 (1957).

10 Ginzburg v. United States, 383 U.S. 463, 470 (1966). See also note 37 infra.

11 Roth v. United States, 354 U.S. 476, 484-85 (1957) ; cf. Jacobellis v. Ohio, 378

U.S. 184, 191 (1964).

12 Ginzburg v. United States, 383 U.S. 463, 479 (1966).

13 Cantwell v. Connecticut, 310 U.S. 296, 310 . (1940) (Roberts, J.).

14 Beauharnais v. Illinois, 343 U.S. 250, 257 (1952) (Frankfurter, J.). 
or, in general, the intellectual component in the psychology of communication, and since he characterizes obscenity as pertaining to the realm of emotion and passion, it follows that for him obscenity is outside the protection of that amendment. ${ }^{15}$ This contrast between reason and the passions is the distinctively formative concept in the emerging constitutional law of obscenity. What is notable and frequently overlooked about Roth $v$. United States ${ }^{16}$ is its abandonment ${ }^{17}$ of the notion, formulated in English and earlier American law, that obscenity should be constitutionally defined in terms of the tendency to "deprave and corrupt." 18 Although a shift away from the "deprave and corrupt" formula had been evident in earlier decisions of federal courts, ${ }^{19}$ Roth completed the replacement of the ambiguous notion of tendency to sexual corruption (which had been accepted even by the Supreme Court ${ }^{20}$ ) with the relatively less ambiguous notion of "appealing to prurient interest." 21 "Corruption" provided an ambiguous standard because it straddled the realms of ideas and passions. Hence, if the first amendment was to protect all expositions of ideas, "corruption" had to be replaced by a formula which unambiguously excluded passions, emotions and desires. Such was the task and achievement of Roth.

Some modern commentators have noted that obscenity may connote not only offensiveness and stimulation, but also an ideological element-that is, ideas capable of undermining the community's sexual philosophy and values. ${ }^{22}$ Commentators rarely recognize, however, that this potentially confusing duality is linked to the ambiguity of the "deprave and corrupt" formula as formerly used by English and

15 A genealogy of this syllogism would include Cantwell v. Connecticut, 310 U.S. 296 (1940); Chaplinsky v. New Hampshire, 315 U.S. 568 (1942); Dennis v. United States, 341 U.S. 494 (1951); Beauharnais v. Illinois, 343 U.S. 250 (1952); Joseph Burstyn, Inc. v. Wilson, 343 U.S. 495 (1952).

16354 U.S. 476 (1957).

17 Id. at 489 .

18 The "deprave and corrupt" test stems from Regina v. Hicklin [1868], L.R. 3 Q.B. 360, 371. For the reception of Hicklin into American law, see United States v. Bennett, 24 F. Cas. 1093, 1104 (No. 14,571) (C.C.S.D.N.Y. 1879); United States v Kennerley, 209 F. 119, 120 (S.D.N.Y. 1913) (L. Hand, J.) ; Slough \& McAnany, supra note 8, at 285-92.

19 See, e.g., United States v. Dennett, 39 F.2d 564, 569 (2d Cir. 1930) ; United States v. One Book Called "Ulysses," 5 F. Supp. 182 (S.D.N.Y. 1933), aff"d, 72 F.2d 705 (2d Cir. 1934); Lockhart \& McClure, supra note 1, at 327-33.

20 See, e.g., Rosen v. United States, 161 U.S. 29, 43 (1896). But cf. Dunlop v. United States, 165 U.S. 486, 500 (1896).

21 Roth v. United States, 354 U.S. 476, 487 (1957).

22 Z. Chafee, Government and Mass Communication 210-12 (1947) ; N. St. JohN-Stevas, OBSCENITY AND THE LAW 126 (1956). Also see the discussions of "thematic" or "ideological" obscenity in Kalven, The Metaphysics of the Law of Obscenity, in 1960 THE Supreme Court ReviEw 1, 3-4, 28-34 (Kurland ed.) ; Lockhart \& McClure, supra note 6 , at 99. 
American courts. ${ }^{23}$ The trial in London, in 1877, of Charles Bradlaugh and Annie Besant for obscene libel illustrates that ambiguity. ${ }^{24}$ The trial was conducted by Lord Chief Justice Cockburn, the author of the so-called Hicklin test. In his remarks to the jury, the judge offered four alternative theories on which the defendants, who had distributed a book about contraception, could be found guilty of depraving and corrupting: (i) if the defendants had a purpose of exciting libidinous thoughts, intending "to give to persons who take pleasure in that sort of thing the impure gratification which the contemplation of such thoughts is calculated to give" ${ }^{25}$ (ii) if the book in fact contained details inconsistent with decency and calculated to enkindle the passions and desires of lust and excite libidinous thoughts; ${ }^{26}$ (iii) if the book had the effect, even if unintended, of corrupting the morals of the unmarried, by suggesting means of escaping a salutary restraint on their sexual conduct; ${ }^{27}$ or (iv) if the book recommended practices of contraception that were contrary to the sound morals that ought to prevail within marriage. ${ }^{28}$ On the fourth theory, the jury was instructed that a man who recommends an immoral course of proceeding in an open publication is guilty, and was warned:

You must decide . . . with a due regard and reference to the law, and with an honest and determined desire to maintain the morals of mankind. But, on the other hand, you must carefully consider what is due to public discussion, and with an anxious desire not, from any prejudiced view of this subject, to stifle what may be a subject of legitimate inquiry. ${ }^{20}$

The third and fourth theories of guilt bestow on the English jury a controlling jurisdiction over the marketplace of ideas, limited only by the jury's self-restraint. It is quite clear that, questions of incitement and imminency of illegal action aside, the analysis just quoted cannot be applied in the United States once the implications of the first amendment are firmly grasped. For in America "even ideas hateful to the prevailing climate of opinion" 30 are constitutionally protected.

23 The ambiguity here discussed is not the ambiguity (as between thought and action) detected in the Hicklin test by Lockhart \& McClure, supra note 1 , at 332-33.

24 In the High Court of Justice, Queen's Bench Division, June 18Th, 1877, The Quegn v. Charles Bradlaugh aNd ANNIE Besant (London, 1877) (a verbatim report). This case is discussed at St. JonN-Stevas, sitpra note 22, at 70-74.

25 The QueEN v. Bradlaugh, supra note 24 , at 261.

26 Id. at 258.

27 Id. at 266.

$28 I d$. at 263.

29 Id. at 265.

30 Roth v. United States, 354 U.S. 476, 484 (1957). 
So the concept of corruption, tainted as it is with a political theory which America has abandoned, has had to be replaced by a concept embodying only the first and second of Lord Chief Justice Cockburn's theories; the result is to preserve the historical notion of obscenity, ${ }^{31}$ while narrowing the definition of obscenity to constitutionally acceptable limits. ${ }^{32}$ The test currently adhered to is Judge Woolsey's test of tendency "to stir the sex impulses or to lead to sexually impure and lustful thoughts," 33 reworked into the Roth test of "appealing to prurient interest." 34

31 The idea of "prurient desires" makes its first appearance in the The Queen $v$. Bradlaugh.

32 Of course, it is true that directions on obscenity have almost always included the notion of suggesting impure and libidinous thoughts or something similar. But, as in Bradlangh, this notion was always linked with, and liable to be affected by, the intrinsic ambiguity of the concept of depraving and corrupting. It was often believed that to preach against accepted moral and sexual ideas might ipso facto arouse lewd thoughts. Cf. Burton v. United States, 142 F. 57, 63 (8th Cir. 1906). That is why, in Bradlangh, Lord Chief Justice Cockburn, without concern, could slip from the test of "tending to suggest unchaste and unclean thoughts, and therefore calculated to lead to immorality," to the test of "tending to influence the passions, or recommending some course of conduct inconsistent with public morals." THE QUEEN V. BRADLAUGH, sispra note 24, at 15, 17 (emphasis added). Cf. United States v. Harmon, 45 F. 414 (C.C.D. Kan. 1891); United States v. Clarke, 38 F. 732, 733-34 (C.C.E.D. Mo. 1889); People v. Wendling, 258 N.Y. 451, 180 N.E. 169 (1932). Sometimes the reference to lustful desires drops out altogether. People v. Dial Press, Inc., 182 Misc. 416, 417, 48 N.Y.S.2d 480, 481 (Magis. Ct. 1944). Also see the cases cited by Lockhart \& McClure, supra note 1, at 334 n.68. As the authors there remark, "even though courts have not often mentioned ideological obscenity as a basis of their decisions, there can be no doubt that it has exerted a powerful influence on the law of obscene literature." Id. at 334. Commonwealth v. Allison, 227 Mass. 57, 116 N.E. 265 (1917), is similar to Bradlaugh, not only in its facts and result, but also in its logic and conceptual structure. 1933).

33 United States v. One Book Called “Ulysses," 5 F. Supp. 182, 184 (S.D.N.Y.

34354 U.S. at 487 . Compare the reasons advanced in Roth for excluding obscenity from the first amendment, id. at 484-85, with those advanced in $E x$ parte Jackson, 96 U.S. (6 Otto) 727 (1878): "In excluding various articles from the mail, the object of Congress has not been to interfere with freedom of the press, . . . but to refuse its facilities for the distribution of matter deemed injurious to the public morals." Id. at 736 (emphasis added).

This necessary evolution in legal analysis is obscured, if not denied, by Professors Lockhart and McClure, when they imply that the Roth test includes the "deprave and corrupt" test, Lockhart \& McClure, Censorship of Obscenity: The Developing Constitutional Standards, 45 MrN. L. REv. 5, 58 (1960), and by Mr. Justice Harlan in Manual Enterprises, Inc. v. Day, 370 U.S. 478, 482-85 (1962). Mr. Justice Harlan's purpose in equating "tendency to deprave" with "prurient appeal," as equally an "effect' element" in obscenity, $i d$. at 484, was simply to facilitate the tour de force by which he derived from Roth both that "effect element" and the "concept of patent offensiveness." Thus, Mr. Justice Harlan states that:

The Court there [in Roth] both rejected the "isolated excerpt" and "particularly susceptible persons" tests of the Hicklin case, 354 U.S., at 488-489, and was at pains to point out that not all portrayals of sex could be reached by obscenity laws but only those treating that subject "in a manner appealing to prurient interest." 354 U.S., at 487 . That, of course, was but a compendious way of embracing in the obscenity standard both the concept of patent offensiveness . . . and the element of the likely corruptive effect

Id. at 487. This analysis in terms of "effects," which obscures the differences of remoteness and causality among arousing lustful thoughts, changing moral ideas and evoking action, probably derives from Lockhart \& McClure, supra note 1, at 329. 
Thus, when Mr. Justice Brennan talks of "expression of ideas," it is in a far more limited sense than that conveyed by ordinary usage. The Brennan theory of free speech is, indeed, as Professor Kalven said, ${ }^{35}$ a two-level theory; one of these levels, moreover, is held to have social utility, and the other not. ${ }^{36}$ But, obscenity is regarded by Mr. Justice Brennan as devoid of relevant or "redeeming" 37 social utility precisely because it pertains, not to the realm of ideas, reason, intellectual content and truth-seeking, but to the realm of passion, desires, cravings and titillation. As such, obscenity belongs to a realm outside first amendment protection. ${ }^{38}$ The two constitutional levels of speech, in effect, are defined in terms of two realms of the human mind.

\section{II}

It might be said, quite truthfully, that the Supreme Court is not bound to subscribe to any particular theory of psychology; one might go on to assert that the alleged two realms or aspects of the human mind are cognizable only within the confines of an outmoded faculty psychology. It is not our present purpose to defend the Court's present stance, nor to establish that it is constitutionally or philosophically necessary, nor even to show that it would be viable in the light of a full understanding of personality. Our aim is simply to emphasize the vital cultural sources of the prevailing view, and to suggest that its foundations are not to be overturned lightly.

Empirical psychology could abandon the distinction between intellect and emotions without the distinction being thereby invalidated either for common-sense or for the philosophy of human nature. The empirical psychologist, by the procedures of experimental science, explores various laws and recurring operations of the human psyche;

35 Kalven, supra note 22 , at 10-16.

36 Id. Kalven's emphasis can be misleading. This is true despite the emphasis on "social utility" in Brennan, The Supreme Court and the Meiklejohn Interpretation of the First Amendment, 79 Harv. L. Rev. 1 (1965). The question that must always be pressed is why obscenity is held by the Court to be without redeeming social merit or value, bearing in mind that the Court is not considering whether or why obscenity should be legislatively proscribed. Failure to put this question apparently derails the argument in Kalven, The New York Times Case: A Note on "The Central Meaning of the First Amendment," in 1964 The Suprene Court Review 191 (Kurland ed.). See note 101 infra.

37 Roth v. United States, 354 U.S. 476, 484 (1957). Notice how the Roth phrase, "redeeming social importance" becomes "saving intellectual content" in Ginzburg v. United States, 383 U.S. 463, 470 (1966).

38 It is ironic that the theory that "such utterances are no essential part of any expression of ideas" originated in $Z$. ChAFEe, FREE SPEech IN the UNITEd STATES 150 (1941), and was repeated by Mr. Justice Frankfurter in Beauharnais v. Illinois, 343 U.S. 250, 257 (1952), for both Professor Chafee and Mr. Justice Frankfurter were radically opposed to absolutism in this area, and both espoused a balancing-ofinterests doctrine. See, e.g., Chafee, Book Review, 62 HARv. L. Rev. 891, 894 (1949); Dennis v. United States, 341 U.S. 494, 524-25 (1951) (Frankfurter, J., concurring). 
and the formulation of these laws and schemes of recurrence may not require use of terms such as "intelligence," "reason," "emotion" or "passions." Both common sense and philosophy, however, are likely to insist that, if the psychologist's own statement of his results is intelligent and reasonable, it is not merely a product of psychic laws and operations, and still less a product of his emotions. By this insistence, common sense and philosophy promote a more comprehensive analysis of human nature, such as Freud proposed when he stated that, although "purely reasonable motives can effect little against passionate impulsions" and "emotional forces," nevertheless "we have no other means of controlling our instinctual nature but our intelligence." 39

The distinction was emphasized by Plato, who likened man's mind to a charioteer (reason) controlling the horses of passions and desires, to a world at war with itself, and to a puppet drawn by the strings of reason and passion. ${ }^{40}$ Aristotle reported that it was the "common opinion" of his own time that weak-willed men act as a result of passion, whereas continent and virtuous men follow their reason, rather than their appetites. ${ }^{41}$ No doubt this remains a general opinion; our culture has been formed not only by the Greeks but also by the Christian awareness that "flesh lusteth against the spirit," ${ }^{42}$ and that "the spirit indeed is willing but the flesh is weak." 43

Still, an appeal to such a philosophy is likely to occasion the remark that the alleged distinction between reason and emotion is nothing but a naive and incoherent dualism, quite unfitted to support reasoned legal distinctions. This criticism, however, is too facile. Philosophy has seen many attempts to explicate the perceived distinction between aspects of the mind, and no doubt some can be convicted of dualist incoherence. But in relying on the distinction, the Justices of the Court would not commit themselves to any particular philosophical explication of it.

39 The Future of an Illusion, in 21 S. Freud, CoMplete Psychological Works $42,47,52$ (J. Strachey ed. 1961).

40 Plato, Phaedrus 246a (3d ed. B. Jowett transl. 1892); 1 Plato, Laws 644d-45c, at 63-65 (R. Bury transl. 1952).

41 Aristorle, Nichomachean Exhics 1145a15-b20 (W. Ross transl. 1925). Aristotle elaborated a complete philosophical psychology of the intellect in his De Anima, and of the passions in his Rhetoric. The Aristotelian theory of virtues is essentially a theory of the harmonious interaction of the rational and sensitively appetitive principles in a man's make-up. It is worth noting, incidentally, that Aristotle and his followers consider that defects in reasonableness, such as imprudence, precipitateness, thoughtlessness and inconstancy, derive from the sensitive appetite for pleasure, and (some add) "above all for sexual pleasure, which quite absorbs the mind and entices it to sensible delights." Aquinas, SUMma Theologias II-II, 53, 6; cf. NichomacheaN ETHICs $1152 \mathrm{~b} 17$.

42 Galatians 5:17. See also Romans 7.

43 Matthew 26:41. 
Now there is another reputable philosophical tradition which believes that: "Reason is, and ought only to be, the slave of the passions, and can never pretend to any other office than to serve and obey them." 44 This formulation is extreme, but Hume's radical softening of the contrast between intellect and emotion has profoundly influenced modern thought. Yet even Hume retains the contrasted notions of reason and passion, though his explanation of the terms and their interrelations might, if adopted, make the two-level theory of speech less attractive (although a Justice, as a private philosopher, might be inclined to ask how Hume's own cool and penetrating intelligence can be reconciled with an account of human nature in which there is such scant place for intelligence and pure reasonableness).

James Madison, who wrote his Federalist papers with Hume's political writings beside him, ${ }^{45}$ shared with Hume that wholly typical eighteenth century outlook which saw human life in terms of a struggle between reason and the passions. But, unlike Hume, Madison stood in the classical tradition, which expressly exalted reason above the passions. Every reader of The Federalist will recall the central importance, in Madison's theory of republicanism, of control of the passions by reason: "[I]t is reason, alone, of the public, that ought to control and regulate the government. The passions ought to be controled and regulated by the government." 46

Madison realized, moreover, that the evils of faction derive from passion; faction, by definition, arises from "some common impulse of passion." ${ }^{47}$ Yet, although "[1] iberty is to faction, what air is to fire, an aliment, without which it instantly expires," 48 liberty in Madison's view "is essential to political life." 40 Clearly, liberty cannot be essential for the sake of allowing passions and faction their sway. Rather, that liberty which is so essential is liberty of opinion, not passions, even if regrettably, "the former will be objects to which the latter will attach themselves." 50

When men exercise their reason coolly and freely on a variety of distinct questions, they inevitably fall into different opinions on some of them. When they are governed by a common passion, their opinions, if they are so to be called, will be the same. ${ }^{51}$

44 Hume, Treatise of Human Nature vol. 2 , pt. $3, \S 2$, in PHILOsophical Works of David Hume 195 ('T. Green ed. 1874).

45 See Adair, "That Politics May be Reduced to a Science": David Hume, James Madison, and the Tenth Federalist, 20 HunTINGTON LIBRARY Q. 343, 358 n.17 (1957).

46 THE FEDERALIST No. 49, at 351 (B. Wright ed. 1961) (Madison).

47 THE FEDERALIST No. 10, at 130 (B. Wright ed. 1961) (Madison).

48 Id.

$49 I d$.

$50 I d$.

51 THe FeDERAList No. 50, at 353 (B. Wright ed. 1961) (Madison). 
Hence, Madison valued freedom of speech because it supplied the community with independent (rational) critics of the government. ${ }^{52}$

It is thus possible to draw a constitutional theorem from the basic thought of The Federalist: to the extent that expressions derive from the passion end of the reason-passion continuum, the rationale for their freedom disappears. Translated into a twentieth century context, this is the basis of the two-level theory in Chaplinsky $v$. New Hampshire ${ }^{53}$ and Roth.

Although the eighteenth century distinction between reason and passion has overtones to which we are now more or less deaf, a similar distinction has preserved a central place in our thought. For example, standard modern textbooks of philosophy contain discussions of the emotive as opposed to the cognitive meaning or force of words, or of cognitivist as opposed to emotivist theories of ethics. The average modern critic of censorship is apt to remark that its supporters are guided by feeling, not reason. There is no point in multiplying examples, for they lie to hand in every field of modern thought.

In short, the two-level theory of speech and of the mind cannot be convicted of provincialism. While it is not the place of a judge to espouse controversial philosophical theories as such, he is entitled, and indeed required, to adopt some viewpoint on human nature by which to orientate his reasoning. $\mathrm{He}$ is not obliged to desist on the plea that his viewpoint may include controverted questions.

\section{III}

The Supreme Court's opinion in Joseph Burstyn, Inc. v. Wilson, ${ }^{54}$ although it deals directly with problems of sacrilege rather than obscenity, and Mr. Justice Stewart's opinion in Kingsley International Pictures Corp. v. Regents of the University of New York ${ }^{55}$ share with $R o t h$ a foundation in the two-level conceptual structure.

Burstyn offered to answer the question "whether motion pictures are within the ambit of protection which the First Amendment . . . secures to any form of 'speech' or the 'the press.'" 56 The major premise of the answer to this significantly worded question was

that motion pictures are a significant medium for the communication of ideas. They may affect public attitudes and

52 Cahn, The Firstness of the First Amendment, 65 Yale L.J. 464, 476 (1956). See also Roth v. United States, 354 U.S. 476, 484 (1957): "The protection given speech and press was fashioned to assure unfettered interchange of ideas for the bringing about of political and social changes desired by the people."

53315 U.S. 568 (1942).

54343 U.S. 495 (1952).

55360 U.S. 684 (1959).

66343 U.S. at 501. 
behavior in a variety of ways, ranging from direct espousal of a political or social doctrine to the subtle shaping of thought which characterizes all artistic expression. ${ }^{57}$

In Kingsley the Court conceded that the film in question presented adultery as a desirable or proper pattern of behavior, and also accepted that the film did not constitute an incitement to illegal action. The Court then determined that:

[w] hat New York has done, therefore, is to prevent the exhibition of a motion picture because that picture advocates an idea-that adultery under certain circumstances may be proper behavior. Yet the First Amendment's basic guarantee is of freedom to advocate ideas. . . . Its guarantee is not confined to the expression of ideas that are conventional or shared by a majority. It protects advocacy of the opinion that adultery may sometimes be proper . . . . And in the realm of ideas it protects expression which is eloquent no less than that which is unconvincing. ${ }^{58}$

But this exposition of the two-level theory of speech raises further questions: Is art constitutionally protected only because it advocates ideas? ${ }^{59}$ Would not such a theory be radically untrue to the nature of art? Would it not make nonsense of the Court's recognition of the redeeming value of art? Indeed, would it not amount to the constitutional canonization of sheer philistinism?

Aesthetics contains a welter of conflicting doctrines, but there is universal agreement that artistic work does not derive its artistic value from any "message" which it may happen to convey and which could be presented in the form of ordinary discursive thinking. Aesthetic attention is not looking at something in order to find out about something. There is universal agreement, too, that art in all its forms neither derives from, nor appeals to, pure reason alone or even primarily. The stock-in-trade of reason is conceptions, definitions, reasons, judgments, doctrines, formulae, arguments, discourse. But

$57 \mathrm{Id}$.

58360 U.S. at 688-89. At a later date, Mr. Justice Stewart attempted to amplify his special notion of "hard-core pornography," as including material which "cannot conceivably be characterized as embodying communication of ideas or artistic values inviolate under the First Amendment." Ginzburg v. United States, 383 U.S. 463, 499 n.3 (1966) (quoting from Brief of Solicitor General).

59 See text accompanying notes 104-08 infra. The question is fairly raised in Kalven, supra note 22 , at $15-16$, and given a simplistic solution in Note, 39 N.Y.U.L. REv. 1063, 1084-85 (1964), and in Note, 34 U. CHI. L. REv. 367, 383 (1967). Semonche, Definitional and Contextual Obscentity: The Supreme Court's New and Disturbing Accommodation, 13 U.C.L.A.L. REv. 1173, 1186-87 (1966) asks: "Is the Court saying that the life of the intellect is more worthy of protection than the life of the imagination?" 
none of these constitute the substance of artistic work or aesthetic experience as such; hence, none of them can constitute the redeeming value of art as art (though it would be absurd to say that they have no place in artistic production or appreciation; literature is art, and criticism thrives). In the foregoing sections of this article, we spoke of another realm, that of emotions and passions. We did not distinguish, within this realm, between sensation, feelings, experience, imagination, emotion. Be that as it may, there is universal agreement that this other realm, however it is to be characterized, is vitally engaged in all artistic work and appreciation. If this is true, what becomes of the constitutional theorem adduced to outlaw obscenity from the protection of the first amendment?

It is to that question that the present section is addressed. The answer proposed is not, perhaps, one that would gain the sort of universal assent mentioned in the foregoing paragraph. But it occupies a central place in the varied doctrines of aesthetics, and commands support, in the main, from widely ranging philosophical traditions. It does not diverge from the common-sense view of the matter, and it is capable of explaining the status accorded to art in our culture and in the theory of the Supreme Court.

By "art," in this account," is meant the "creation of forms symbolic of human feeling." ${ }^{11}$ A symbol is a sensuous object which by virtue of its highly articulated structure can express the forms of vital experience-feeling, life, motion and emotion-which purely intellectual discourse cannot convey. The contrast, noted above, between rational discourse and art is so marked that superficial thinkers are tempted to suppose that the function of art is to stimulate feelings. ${ }^{62}$ But an artist is not a manipulator who, having studied the psychology of his audience, allows his findings to guide his work; he is not a cook selecting the recipes that will appeal to the palate. ${ }^{63}$ Aesthetic attention is not to be equated with the exploitation of gratifying sensory stimulants. What makes art art is not that it stimulates feelings, which any family picture album can do, ${ }^{64}$ but that it expresses them symbolically. To be

60 This account is primarily based on the ideas and terminology of S. LANGER, FEEIING AND FORM (1953). It also draws on other traditions, such as the "Oxford" linguistic school and neo-Thomism, as indicated in following notes.

$61 I d$. at 40 .

62 Id. at 18.

63 Id. at 107. See also Strawson, Aesthetic Appraisal and Works of Art, OxFord REvIEw Oct. 1966, at 12: ". . . an aesthetic interest in an individual is not any kind of practical interest, not an interest in anything it can or should do, or that we can do with it, not even an interest in specific responses (say, excitement or stupefaction) which it will produce in us. (If it were this sort of interest, there could indeed be general rules and recipes.)"

64 See R. Berger, The Language of Art 32 (1963). 
more precise, art expresses ideas of feeling, ${ }^{65}$ and it does this by embodying these ideas in the more or less conventional symbolic forms ${ }^{66}$ of music, painting, sculpture, architecture, poetry, drama and prose.

Just as an actor does not vent his own emotions, but conceives and enacts the emotions of the character being played, ${ }^{67}$ so the creative artist is not so much venting his own emotions, as imagining and conceiving emotions and feelings in such fashion that his understanding of them can be communicated through the symbolic form of his chosen art. $^{88}$ Art, then, gives to those who attend to it aesthetically, an insight into the life of feeling, vitality and emotion. ${ }^{69}$ But it communicates the insight not by discourse, reasoning or judgments, not by saying anything about the nature of feeling, but by showing it in symbolic form. ${ }^{70}$ This is even true of the symbolic forms of the literary arts that use propositional discourse as their material. ${ }^{11}$ "[T]he emotion in the work is the thought in the work"; "the sensuous quality is in the service of its vital import." 73

Artistic creation and appreciation, then, operate between the two main levels of the mind. Art forces a modification of the two-aspects theory of the mind, ${ }^{74}$ since the peculiar triumph of art is to weld these levels of experience in a unique way that gives deep emotional and

65 S. LANGER, supra note 60 , at 59. See also R. BERGER, supra note 64 , at 54 : "Instead of trying to define the truth as an idea does, form seeks to convey the feeling, the sensation of truth. By its means truth ceases to be an abstract notion and becomes an experience." Berger's terminology differs from Langer's, but the thought is the same.

${ }^{66}$ See S. LANGER, supra note 60 , at 280.

$67 I d$. at 323.

$68 I d$. at 28.

$69 \mathrm{Id}$. at 129. See also J. Maritain, Art and Scholasticism 163 (3d ed. J. Evans transl. 1962) : "[i]n the perception of the beautiful the intellect is, through the means of the serwible intuition itself, placed in the presence of a radiant intelligibility

70 S. LANGER, supra note 60 , at $227,393$.

If it [the intellect] turns away from sense to abstract and reason, it turns away from its joy and loses contact with this radiance.

To understand this, let us recall that it is intellect and sense as forming but one, or, if one may so speak, the intellegentiated sertse, which gives rise in the heart to aesthetic joy.

J. MaritaIN, supra note 69 , at 164. See also Analytic of the Beautiful $\$ 15$, in I. Kant, Critique of Aesthetic Judgment (J. Meredith trans1. 1911).

71.Cf. Henry Miller, Obscenity and the Laze of Reflection, $51 \mathrm{Ky}$. L.J. 577, 582 (1963): ". . . painters, however unapproachable their work may be, are seldom subject to the same meddling interference as writers. Language, because it also serves as a means of communication, tends to bring about weird obfuscations."

72 S. LANGER, supra note 60 , at 82.

73 Id. at 59. See also Kaplan, Obscenity as an Aesthetic Category, 20 LAW \& Contedrp. Prob. 544, 548 (1955).

74 Such a modification is attempted in Jenkins, The Human Function of Art, 4 Prmosophical Q. 128 (1954). He argues that the three relevant aspects of the psyche are the "affective," "aesthetic" and "cognitive." 
intellectual satisfaction. ${ }^{75}$ In artistic experience, sentience is liberated from the drag of biological relevance, while intelligence is liberated from the constraints of discursive reasoning. ${ }^{76}$

This is why aestheticians of every school have insisted on the requirement of detachment, "contemplation," "aesthetic" attitude or attention,

Of course, artistic works affect people otherwise than as art, just as pictures activate almost every one's imagination, but only clear and intuitive minds really understand the vital import, while the average person reacts to the things depicted, and turns away if he can find nothing to promote his discursive thoughts or stimulate his actual emotions. ${ }^{77}$

or objectivity. It is the basis for the aesthetic psychologist Edward Bullough's famous theory of the need for "psychical distance" between the work and its public (including the artist). ${ }^{78}$

Professor Bullough believed this distance is obtained by "separating the object and its appeal from one's self, by putting it out of gear with practical needs and ends." 79 It does not imply a purely intellectual or impersonal relation between man and work, but a peculiar relation "filtered" of the "practical, concrete nature of its appeal." 80 The ideal in both creation and appreciation is the "utmost decrease of Distance without its disappearance." 81

The ability to maintain this distance varies. ${ }^{82}$ Artists can distance even the most personal affections sufficiently to make them aesthetically appreciable, at least to themselves. For the average person, however, "a limit does exist which marks the minimum at which his appreciation

75 S. LANGER, supra note 60 , at 397.

76 See B. LoNERGAN, INSIGHT 185 (1957).

77 S. LANGER, supra note 60 , at $166-67$.

78 See id. at 318; E. Bullougr, Aestherics 93-130 (1957). On the vital relevance of "distance" to aesthetic experience, and its incompatibility with obscenity or pornography, see Kaplan, supra note 73, at 548: "Only when we hold the work of art at arm's length is it artistic at all. The work brings emotions to mind or presents them for contemplation. When they are actually felt, we have overstepped the bounds of art." See also Gardiner, Moral Principles Tozerards a Definition of the Obscene, 20 LAw \& Contens. Pros. 560, 563 (1955). The concept of distance makes a Supreme Court appearance in Mr. Justice Brennan's footnote quotation from a dissenting opinion in the lower court, in Memoirs v. Massachusetts, 383 U.S. 413,415 n.2 (1966).

79 E. BuLlougH, supra note 78, at 96.

${ }^{80} \mathrm{Id}$. at 97 . See also S. LANGER, supra note 60 , at 49 :

Schiller was the first thinker who saw what really makes "Schein," or semblance, important for art: the fact that it liberates perception-and with it, the power of conception-from all practical purposes, and lets the mind dwell on the sheer appearance of things.

81 E. Bullough, supra note 78 , at 100 .

82 This, and what follows, is the most solid basis for the concept of "variable obscenity." Arguments for the concept more usually have been based on a balancingof-interests analysis which, as we have argued, is not the bedrock of the present law. See Gerber, A Suggested Solution to the Riddle of Obscenity, 112 U. PA. L. REv. 834, 847-56 (1964); Lockhart \& McClure, Censorship of Obscenity: The Developing Constitutional Standards, 45 MinN. L. REv. 5, 68-88 (1960). 
can maintain itself in the aesthetic field," 83 and as this limit varies from person to person, so it varies from time to time, from subjectmatter to subject-matter and from culture to culture. ${ }^{84}$ In general, "explicit references to organic affections, to the material existence of the body, especially to sexual matters, lie normally below the Distancelimit, and can be touched upon by Art only with special precautions." 85 Professor Bullough and his adherents were not concerned with discussing obscenity and pornography, and still less with condemning them. But within their conceptual scheme it is easy to characterize the pornographer as one calculating to avoid all the "special precautions" with which art must handle certain topics, if the psychical distance necessary for aesthetic appreciation is to be maintained. Some ages and cultures require fewer precautions than others; but whichever are required at any given time and place, the pornographer is the man who sets out to defy them. . $^{s 6}$

The techniques by which the pornographer deliberately destroys the aesthetic attitude include the attribution of male psychology to the female, the arousing of identification with, and the compelling of envy for, the fictional characters in their sexual opportunities and exploits, ${ }^{87}$ and many other narrative and descriptive devices which may profitably be analyzed. ${ }^{88}$ The designed effect of these techniques is always the same-the replacement of aesthetic attention to the material with an attitude in which the practical concerns of the reader or viewer (in this case, a concern to achieve the emotionally aroused states which he desires for himself) intrude upon and suppress an understanding contemplation of the created symbol. ${ }^{89}$

83 E. Bullough, supra note 78, at 101 ; cf. Commonwealth v. Buckley, 200 Mass. 346, 86 N.E. 910 (1909).

84 S. LANGER, supra note 60 , at 319 . Distance also varies from context to context. Hence, the concept of variable obscenity, which seems to have been adopted in Ginzburg v. United States, 383 U.S. 463 (1966).

85 E. BuLlougH, supra note 78, at 101.

86 See Kaplan, supra note 73, at 548: "Now pornography is promotional: it is the obscene responded to with minimal psychic distance .... [A]s to esthetic intent, this is lacking altogether in so far as the object is being read as pornographic." As the psychologist van den Haag remarks, aesthetic merit is likely to reduce, if not to eliminate, rather than augment the obscene effect. "The pinup has it all over art, if it comes to sheer erotic stimulation." Haag, Quia Ineptnm, in "To DEPRAve AND CoRrupr . . 111, 118 (J. Chandos ed. 1962). Thus, also, Santayana's famous theorem, that beauty tends to cancel lust. G. SANTAYANA, REASON IN ART 171 (1934). 87 Cf. Sylvester, Tassels, and Other Gadgets, ENCounTER, June 1966, at 36, 38. 88 See the attempts set out in Lockhart \& McClure, supra note 82, at 58-68. 89 See Henry Miller's remark:

When obscenity crops out in art, in literature more particularly, it usually functions as a technical device; the element of the deliberate which is there has nothing to do with sexual excitation, as in pornography. . . Its purpose is to awaken, to usher in a sense of reality.

Miller, supra note 71, at 587. Obviously, what Miller (and Kaplan, supra note 73) calls "obscenity" would in principle, on our analysis, be constitutionally protected art, and not obscene. 
This is not to argue that obscenity should be proscribed because it destroys aesthetic appreciation or threatens art, nor, indeed, that it should be proscribed for any other reason. The concern of this article is not with the rights and wrongs of obscenity, but with the purely constitutional question of whether obscenity is within the first amendment's protected area of "speech." Under the present constitutional dispensation, expression is protected "speech" precisely to the extent that it derives from and appeals to the intellectual end of the intellect-emotion continuum. The relevant implication of our discussion of psychical distance and its destruction by obscene expression is this: expression that threatens psychical distance does so by shifting its appeal towards the emotion end of the intellect-emotion continuum, and by suppressing the intellectual component in the aesthetic attitude.

The aesthetic attitude is constituted by a unique balance of intellect and feeling in the contemplation and grasp of a symbol that expresses the idea of emotion or feeling. In Langer's words, psychical distance is simply "Our natural relation to a symbol that embodies an idea and presents it for our contemplation . . . "cleared of the practical nature of its appeal." " 90 It is intelligence that contemplates and grasps ideas, in whatever form they are embodied; the ideas in art are embodied in a sensuous symbol. Hence, whatever attacks contemplation and aesthetic understanding must, by the same token, obscure the expressive and intelligible form of the work as symbol, leaving only its potentiality for being used to stimulate feelings.

Burstyn $^{91}$ and Kingsley Pictures ${ }^{92}$ imply that art by definition must fall within the area of what is constitutionally protected "speech." It would be a mistake, however, to adopt a simplistic notion ${ }^{93}$ of the sort of idea that art expresses. That idea is not a "message" or doctrine that ratiocination can conceive or discourse communicate. It is the symbol of feeling, whose sensuous quality is in the service of its vital import and whose unique power "lies in the fact that it is an abstraction, a symbol, the bearer of an idea." 94 Art "gives us forms of imagination and forms of feeling." ${ }^{55}$ Usually, "when one speaks of 'reason' at all, one tacitly assumes its discursive pattern." ${ }^{98}$ Such an assumption might be thought to lie behind the Kingsley Pictures explanation of art's status within the protected realm of ideas, intellect

$90 \mathrm{~S}$. LANGER, supra note 60 , at 319.

21 Joseph Burstyn, Inc. v. Wilson, 343 U.S. 495 (1952).

92 Kingsley Int'l Pictures Corp. v. Regents of Univ. of N.Y., 360 U.S. 684 (1959).

83 See, e.g., Note, 39 N.Y.U.L. Rev. 1063, 108485 (1964).

$94 \mathrm{~S}$. LANGER, supra note 60 , at 47.

95 Id. at 397 (emphasis in original).

98 Id. at 29. 
and reason. "But in a broader sense any appreciation of form ... is 'reason'; and discourse with all its refinements . . . is only one possible pattern." ${ }^{97}$

In sum, artistic creation and appreciation, though they do not belong to the realm of ideas rather than to the realm of emotions, are, in a special way, at least as irreduciably bound up with intelligence as with feeling. ${ }^{98}$ It remains only to point out that, though practical diffculties of characterization are undeniable, obscene expressions as constitutionally defined cannot claim the protection due to art; to the extent that an appeal is made to prurient interest, the psychical distance essential to an aesthetic attitude is liable to be destroyed. Such destruction is achieved, moreover, in a precisely relevant fashion; it disrupts the contemplative and intellectual component of the aesthetic attitude and, through direct emotional stimulation, obscures the idea which the work, as art, symbolically expresses and communicates to those willing to give it the aesthetic attention required to understand it.

\section{IV}

It remains only to show in more detail how the dialectic of "reason" and "passion" has shaped the constitutional law of obscene expression. We have already argued that the two-level or reasonpassion theory provides a working rationale for the application or refusal of constitutional protection to expressions alleged to be obscene. In fact, it is clear that whenever the type of speech, as distinct from the time, place and manner of expression, is in issue the majority on the Court will respond to the seminal passage in Chaplinsky:

Such utterances are no essential part of any exposition of ideas, and are of such slight social value as a step to truth that any benefit that may be derived from them is clearly outweighed by the social interest in order and morality. ${ }^{99}$

The constitutional premise of this passage is clarified by New York Times Co. v. Sullivan:

97 Id. (emphasis added).

98 See R. BERGER, supra note 64, at 80: ". . . aesthetic awareness is at one and the same time an experience and a judgment. $\therefore$. As critic Clive Bell has said: Before we feel an aesthetic emotion for a combination of forms, do we not perceive intellectually the rightness and necessity of the combination? If we do, it would explain the fact that passing rapidly through a room we recognize a picture to be good, although we cannot say that it has provoked much emotion.

C. BeIL, ART 26 (1914).

99315 U.S. 568, 572 (1942). This passage has been quoted many times. See, e.g., Garrison v. Louisiana, 379 U.S. 64, 75 (1964) (libel case); Roth v. United States, 354 U.S. 476, 485; Beauharnais v. Illinois, 343 U.S. $250,256-57$ (1952). See also the reference to "the dissemination of information" in United States v. Carolene Products Co., 304 U.S. 144, 152 n.4 (1938). 
The constitutional safeguard, we have said, "was fashioned to assure unfettered interchange of ideas for the bringing about of political and social changes desired by the people." 100

The constitutional protection does not turn upon "the truth, popularity, or social utility of the ideas and beliefs which are offered." 101

Even Justices Black and Douglas pay an oblique tribute to this implicit constitutional reliance on the contrast between reason and passion, by their repeated allegations that the Court has refused to protect "discussion or opinions" ${ }^{102}$ in the obscenity cases. Thus sadomasochistic fiction sold at a profit of several thousand percent is euphemistically referred to by Mr. Justice Black as "views about sex" and "subjects discussed." 103

Only the dictum in Winters v. Nerw York 104 that "we do not accede to appellee's suggestion that the constitutional protection for a free press applies only to the exposition of ideas," 105 seems to stand in the way of this kind of analysis. But the meaning of this passage is clarified by what immediately follows:

The line between the informing and the entertaining is too elusive for the protection of that basic right. Everyone is familiar with instances of propaganda through fiction. What is one man's amusement, teaches another's doctrine. ${ }^{108}$

Hence, the foregoing dictum in Winters is capable of being explicitly absorbed into the two-level reasoning of Burstyn that "motion pictures are a significant medium for the communication of ideas." 107 Despite its protestations, the Court in Winters was protecting entertainment, at least in part because of its significance in the exposition of ideas

100376 U.S. 254, 269 (1964) (quoting Roth).

$101 \mathrm{Id}$. at 271 (quoting N.A.A.C.P. v. Button, 371 U.S. 415, 445 (1963)). This passage shows how wide of the mark Kalven was, supra note 36 , at $217-18$, in announcing that the Times case disposed of the two-level theory. As did other commentators, Kalven leapt from the premise that "'mere labels' of state law" cannot control constitutional judgment, to the conclusion that no category of speech is any longer beneath the protection of the first amendment. The mistake lies in forgetting that the obscenity which is beneath first amendment protection, on the twolevel theory, is not a "mere label of state law" claiming "talismanic protection" but a category which has ex hypothesi been "measured by standards that satisfy the first amendment" before being declared outside the protection of that amendment. See also New York Times Co. v. Sullivan, 376 U.S. 254, 265-66, 270 (1964).

102 See, e.g., Mishkin v. New York, 383 U.S. 502, 517 (1966) (Black, J., dissenting).

${ }^{103} \mathrm{Id}$. at $516-17$.

104333 U.S. 507 (1948).

$105 \mathrm{Id}$. at 510 .

${ }^{106} I d$.

107343 U.S. at 501 (emphasis added). 
as "propaganda" and "doctrine." An answer to the dilemma with which the Court was struggling in Winters, Burstyn and Kingsley Pictures $^{108}$ lies in the recognition that, quite apart from propagation of doctrine, some "entertainments" have artistic value, meaning and symbolic significance and appeal to contemplation and understanding, while others appeal to the sensual emotions in order to achieve a calculated effect of obfuscating understanding with titillation, stimulation and gratification.

A further question now arises, however, for if there is a simple bedrock rationale for the exclusion of obscenity from constitutional protection, that rationale can be expected to manifest itself in some, if not all, ${ }^{109}$ of the tests used in defining "obscenity." Such indeed is the case. We argued in the first section that the adoption of the "prurient interest" test and the abandonment of the "deprave and corrupt" test, are ascribable to the two-level theory that obscenity pertains to passion rather than reason. Appeals to passion are not the concern of the first amendment; hence the priority of the prurient interest test ever since the constitutional issue was squarely faced. The cases since Roth confirm that the phrase "prurient interest" was not intended by the Court to have the limited meaning attached to it by the Model Penal Code:

an exacerbated, morbid, or perverted interest growing out of the conflict between the universal sexual drive of the individual and equally universal social controls of sexual activity. ${ }^{110}$

It has been argued that, under such a formulation, "totally erotic" material might escape sanctions because it does not produce a sense of guilt and shame in the average man. ${ }^{111}$ But a Court which considers as synonyms for "prurient interest," phrases such as "Iustful thoughts," "lascivious longings," 112 "erotic interest," 113 "titillation" 114 and "erotically arousing" material providing "sexual stimulation" 115 to the "salaciously disposed," 116 would hardly accede to such an argu-

108 Kingsley Int1 Pictures Corp. v. Regents of Univ. of N.Y., 360 U.S. 684 (1959). See text accompanying notes $54-60$ sipra.

109 Even a bedrock rationale need not be pushed to the full limits of its logic; it may be qualified by competing rationales or considerations. $C f$. H. L. A. Hart, Prolegonenon to the Principles of Punishment, in PHILOSOPHy, Politrcs AND Socrety 158, 160 (2d ser. Laslett \& Runciman eds. 1962).

110 Model Penat Code $\$ 207.10$, Comment 6(c) (Tent. Draft No. 6, 1957).

111 Note, 51 CORNELI I.Q. 785, 789 (1966).

112 Roth v. United States, 354 U.S. 476, 487 n.20 (1957).

113 Id. at 496 (Warren, C.J., concurring).

114 Ginzburg v. United States, 383 U.S. 463, 470 (1966).

$115 \mathrm{Id}$. at 471.

118 Id. (quoting United States v. Redbuhn, 109 F.2d 512 (2d Cir. 1940) Hand, J.)). 
ment. "Passions," in the two-level theory, are not tricked out with psychological theories of "psycho-social tension." 117 The fundamental question is simple: does the reader look for "titillation" or for "intellectual content"? ${ }^{118}$

The second of the three definitive elements of obscenity, as crystallized in Memoirs $v$. Massachusetts, requires that "the material is utterly without redeeming social value." 118 The link between this test and the underlying reason-passion rationale, though not selfevident, is revealed by the Court's incorporation in Memoirs $v$. Massachusetts ${ }^{120}$ of Mr. Justice Brennan's comment in Jacobellis $v$. Ohio that "material dealing with sex in a manner that advocates ideas . . . or that has literary or scientific or artistic value or any other form of social importance, may not be branded as obscenity ." 121 This list of species of socially valuable material indicates the intended character of the whole genus; it suggests that relevant social importance derives from connection, direct or indirect, with the intellectual realm. At the same time, assuming some consensus in the relevant levels of American culture, this second defining element provides the courts with a broad common-sense criterion ("social importance") in place of the intricate and controversial philosophical categories which underpin that criterion, and which we have illustrated in the preceding sections.

The third defining element of obscenity named in Memoirs $v$. Massachusetts is that of patent offensiveness and affront to contemporary community standards relating to the description or representation of sexual matters. Offensiveness correlates with that which destroys psychical distance for a given culture, person and context. There are people, of course, who often like to eliminate distance, but others feel threatened and shocked when confronted with objects that might overcome their ability to distance and their rational control. Moreover, ability to maintain distance varies widely. The test of patent offensiveness as judged by current community standards seeks to ensure that the law is geared to an average standard of robustness in these matters. The test tends to protect at least the "classics," since current community standards can be taken to recognize implicitly that the classics are part of, rather than offenders against, those standards

117 See ModeI. PeNal Cone \$207.10, Comment 6(c) (Tent. Draft No. 6, 1957). 118 Ginzburg v. United States, 383 U.S. 463, 470 (1966). The fact that the notion of "arousing lustful thoughts" is central to the constitutional rationale for excluding obscenity from the first amendment does not imply that the same notion need be central to the legislative rationale for proscribing obscenity. See section V of text infra.

119383 U.S. at 418.

$120 \mathrm{Id}$. at 419 n.7.

121378 U.S. 184, 191 (1964). 
and that the classics discipline, rather than disturb, people's ability to maintain psychical distance. The use of the test in Ginzburg is evidence of its connection with the reason-passion rationale, for Mr. Justice Brennan says that to represent one's publications as erotically arousing not only stimulates the reader to look for titillation rather than intellectual content, but also "would tend to force public confrontation with the potentially offensive aspects of the work" and "heightens the offensiveness of the publications to those who are offended by such material." 122

Finally, the reason-passion theory of the first amendment fits closely the Court's increasing concern with commerciality. As Ginzburg indicates, the Court will judge the obscenity of publications

. . against a background of commercial exploitation of erotica solely for the sake of their prurient appeal. ${ }^{123}$

"[I]f the object [of a work] is material gain for the creator through an appeal to the sexual curiosity and appetite," the work is pornographic. ${ }^{124}$

The relevance of commerciality is not that the seller profits from his activity; ${ }^{125}$ rather, the fact that he is a mere seller might indicate that he is not trying to engage in activity protected by the first amendment, i.e., the communication of ideas in whatever form.

The panderer is participating in the marketplace of prurient interest, not in the marketplace of ideas. His participation, therefore, will be taken at face value, even if the material is not devoid of value. ${ }^{120}$ This emphasis on commercial exploitation is wholly consistent with the two-level theory. The two levels of the marketplace correlate with the two functional levels of the mind; to "peddle" material to the public on the strength of its appeal to the passions tends to negative any intrinsic social value the material may have and to remove it from the level of constitutionally protected speech.

The foregoing discussion of the current tests for defining obscenity attempts merely to indicate the conceptual link between these tests and the fundamental two-level rationale; it is not intended as a full exposition of the tests, still less as an exploration of the many practical legal problems that they raise. Nor does it attempt to show

122383 U.S. at 470 .

$123 \mathrm{Id}$. at 466 .

124 Id. at 471.

125 Id. at 474-75 (1966); Joseph Burstyn, Inc. v. Wilson, 343 U.S. 495, 501 (1952).

126383 U.S. at 470 . It is the participation in the marketplace, not the work as such, that is suppressed in this case. 
that these tests are preferable to others which might be derived from the same rationale. For example, the test championed by Justices Clark and White in Memoirs v. Massachusetts ${ }^{127}$ is just as derivable from the reason-passion rationale as is the test of redeeming social value; the selection of one in preference to the other will depend on other factors. A rationale may be recognized as fundamental, without being adopted as exhaustive and exclusive of all other constitutional or legal considerations.

\section{V}

We have been discussing why obscene expression is outside the first amendment. Nothing we have said has been directed to the questions of whether and why obscenity should be regulated. A discussion of these questions would take us far afield, not only into empirical enquiries but also into the fundamental question of whether our criminal law is, and ought to be, designed to eliminate "harms" or whether it also seeks, and should seek, to express, vindicate and uphold wider values. Moreover, there is no reason why any rationale for excluding obscenity from constitutional protection must coincide with a rationale for proscribing obscenity by criminal or administrative measures.

Still, the approach we have described has three advantages over alternative approaches. First, the prurient interest test does have an explicit and intelligible connection with the rationale for excluding obscenity from constitutional protection. That rationale is the twolevel theory. On the other hand, the "hard-core pornography" test ${ }^{128}$ has no intelligible connection with any constitutional rationale for denial of first amendment protection, except perhaps in Mr. Justice Stewart's suggestion that hard-core pornography "cannot conceivably be characterized as embodying communication of ideas" ${ }^{128}$ - in which case the rationale is the same as that adopted by Mr. Justice Brennan. The question then must be why the modified prurient interest test should not be adopted in place of the uninformative notion of "hardcore pornography." 130

127383 U.S. at 441-42 (Clark, J., dissenting); id. at 461-62 (White, J., dissenting).

128 The test is employed differently by $\mathrm{Mr}$. Justice Harlan in relation to federal censorship, e.g., Ginzburg v. United States, 383 U.S. 463, 493 (1966) (Harlan, J., dissenting), and by Mr. Justice Stewart generally. E.g., id. at 499 (Stewart, J., dissenting); Jacobellis v. Ohio, 378 U.S. 184, 197 (1964) (Stewart, J., concurring). 129 Ginzburg v. United States, 383 U.S. 463, 499 n.3 (1966).

130 It is interesting that in Magrath, The Obscenity Cases: Grapes of. Roth, in 1966 ThE SUPREME COURT REviEw 7 (Kurland ed.), the attempt to explain "hard-core pornography" falls back on "patent offensiveness" plus a "self-defining" element found 
Second, the reason-passion theory of speech has the merit of emphasizing the serious unreality of Justices Black and Douglas's notion that men like Roth, Alberts and Mishkin are somehow engaged in the same activity- "expression of views and opinion"-as are the bona fide participants in the marketplace of ideas, who advance the contest of reason visualized in the Federalist.

Third, the theory that obscenity is not protected speech has the advantage of not involving the Court in a "balancing-of-interests" test. For in such a speculative and controversial area, any attempt to balance interests or even to articulate the rationale for proscribing obscenity, would be beyond judicial competence. It is better left to the experiments of legislatures and the changing worldly-wisdom of juries, working within the relatively narrow area now left them by the Court.

in "writings designed to act as psychological aphrodisiacs or stimulants," id. at 72, where

[t] he reader is meant to identify either with the narrator... or with the general situation to a sufficient extent to produce at least the physical concomitants of sexual excitement ... that he would have were he taking part in the activities described.

Id. (quoting Gorer, in Does Pornography Matter? 32 (C. Rolph ed. 1961)). This amounts to little more (or less) than a deliberate "appeal to prurient interest," accomplished by the destruction of aesthetic distance. Magrath's suggestion that discovery of this second "element" involves "attention solely to the material per se," id. at 74, cannot be admitted; to discover whether material is "too sexually arousing," $i d$. at 75 , one has to look beyond "the material alone" to its "prurient interest to some hypothetical average person." In any event, Magrath's test, if adopted, would rest on the same bedrock rationale as the current test. 